\title{
Enhanced expression levels of aquaporin-1 and aquaporin-4 in A549 cells exposed to silicon dioxide
}

\author{
XIAOHUI HAO ${ }^{1 *}$, HONGLI WANG ${ }^{2 *}$, WEI LIU ${ }^{2}$, SHUPENG LIU $^{1}$, ZIHE PENG $^{1}$, \\ YUE SUN $^{1}$, JINYUAN ZHAO ${ }^{3}$, QIUJIE JIANG ${ }^{4}$ and HELIANG LIU ${ }^{1,2}$ \\ ${ }^{1}$ Medical Research Center; ${ }^{2}$ School of Public Health, North China University of Science and Technology, Tangshan, Hebei 063000; \\ ${ }^{3}$ The Occupational Medicine Research Center, Peking University Third Hospital, Beijing 100191, P.R. China; \\ ${ }^{4}$ Department of Dermatology and Cutaneous Biology, Thomas Jefferson University, Philadelphia, PA 19107, USA
}

Received September 6, 2015; Accepted May 31, 2016

DOI: $10.3892 / \mathrm{mmr} .2016 .5481$

\begin{abstract}
Aquaporins (AQPs), water channel proteins in the cell membranes of mammals, have been reported to be important in maintaining the water balance of the respiratory system. However, little is known regarding the role of AQP in occupational pulmonary diseases such as silicosis. The present study investigated the expression of AQP1 and AQP4 in the human A549 alveolar epithelial cell line stimulated by silica $\left(\mathrm{SiO}_{2}\right)$. A549 cells were cultured and divided into four groups: Control, $\mathrm{SiO}_{2}$-stimulated, AQP1 inhibitor and AQP4 inhibitor. The cells of the $\mathrm{SiO}_{2}$-stimulated group were stimulated with $\mathrm{SiO}_{2}$ dispersed suspension $(50 \mathrm{mg} / \mathrm{ml})$. The cells of the inhibitor group were pretreated with mercury (II) chloride $\left(\mathrm{HgCl}_{2}\right.$; a specific channel inhibitor of AQP1) and 2-(nicotinamide)-1,3,4-thiadiazole (TGN-020; a specific channel inhibitor of AQP4) and stimulated with $\mathrm{SiO}_{2}$. The mRNA expression levels of AQP1 and AQP4 were detected by reverse transcription-quantitative polymerase chain reaction, and the protein expression levels of AQP1 and AQP4 were detected by western blotting and immunocytochemistry. Compared with the control group, the expression levels of AQP1 and AQP4 mRNA and protein in $\mathrm{SiO}_{2}$-stimulated groups increased and subsequently decreased (AQP1 peaked at $2 \mathrm{~h}$ and AQP4 at 1h; both $\mathrm{P}<0.001$ compared with control group). In the inhibitor group, expression levels were increased compared with controls; however, they were significantly decreased compared with the $\mathrm{SiO}_{2}$-stimulated group at $2 \mathrm{~h}(\mathrm{AQP} 1 ; \mathrm{P}<0.001)$ and $1 \mathrm{~h}$ (AQP4; $\mathrm{P}<0.001)$. The expression of AQP1 and AQP4 increased when exposed to $\mathrm{SiO}_{2}$, and this was inhibited by $\mathrm{HgCl}_{2}$ and TGN-020, suggesting that AQP1 and AQP4 may contribute to
\end{abstract}

Correspondence to: Professor Heliang Liu, Medical Research Center, North China University of Science and Technology, 57 Jianshenan Road, Tangshan, Hebei 063000, P.R. China

E-mail: tsruoshui@163.com

*Contributed equally

Key words: aquaporin-1, aquaporin-4, silicon dioxide, A549 cells, silicosis
A549 cell damage induced by $\mathrm{SiO}_{2}$. AQP1 and AQP4 may thus be involved in the initiation and development of silicosis.

\section{Introduction}

Silicosis is a fibrotic lung disease caused by inhalation of free crystalline silicon dioxide or silica. Occupational exposure to respirable crystalline silica dust particles occurs in many industries (1). To date, there is no general therapy for the treatment of this disease. In 1997, the International Agency for Research on Cancer upgraded crystalline silica to a Group 1 human carcinogen (2). Despite extensive research efforts, the exact mechanism of silicosis remains to be fully elucidated (3).

Silica $\left(\mathrm{SiO}_{2}\right)$ dust is the critical pathogenic factor in the initiation of silicosis (4), and the alveolar epithelial cells of the lung are the primary target cells, particularly in the early stages of the disease. However, the underlying molecular mechanism of epithelial cell damage induced by $\mathrm{SiO}_{2}$ remains to be elucidated (5). Aquaporins (AQPs), of which there are 13 subtypes (AQP0-AQP12), are cell membrane transport proteins associated with water permeability. AQPs are widely distributed in animals and plants and their important role in water transport has been extensively investigated (6-8). AQP1 was first reported in 1992 (9), and has been demonstrated to be ubiquitously involved in the water balance of the respiratory system (10-13). In addition, AQP4 regulates the exchange of fluid between the alveolar space and alveolar epithelium barrier and has a significant compensational role in pulmonary liquid clearance in the event of sodium transport damage in acute lung injury $(14,15)$. However, a limited number of studies have investigated the involvement of AQP1 and AQP4 in occupational pulmonary diseases, such as silicosis $(16,17)$. Therefore, in the present study, human A549 type II alveolar epithelial cells cultured in vitro were stimulated with $\mathrm{SiO}_{2}$ dust to investigate possible mechanisms of AQP1 and AQP4 in the pathological process of silicosis. This may provide an experimental basis to identify effective targets for the prevention and control of silicosis.

\section{Materials and methods}

Reagents. Crystalline silica (MIN-U-SIL5 ${ }^{\circledR} ; \mathrm{SiO}_{2}$ purity, 99.2\%; median particle diameter, $1.6 \mu \mathrm{m}$ ) was purchased from 
U.S. Silica (Frederick, MD, USA). RPMI-1640 culture medium was supplied by HyClone; GE Healthcare Life Sciences (Logan, UT, USA). Fetal bovine serum (FBS) and 0.25\% trypsin were purchased from Gibco; Thermo Fisher Scientific, Inc. (Waltham, MA, USA). TRIzol ${ }^{\circledR}$ Reagent for total RNA extraction was purchased from Invitrogen; Thermo Fisher Scientific, Inc. The Moloney Murine Leukemia Virus Reverse Transcriptase RNase H Minus Point Mutant kit and SYBR Green quantitative polymerase chain reaction (qPCR) reagent kit were products of Promega Corporation (Madison, WI, USA). Anti- $\beta$-actin rabbit polyclonal antibody (ab8227) was purchased from Abcam (Cambridge, MA, USA) and anti-AQP1 (sc-20810) and anti-AQP4 (sc-20812) rabbit polyclonal antibodies were purchased from Santa Cruz Biotechnology, Inc. (Dallas, TX, USA). Horseradish peroxidase-conjugated sheep anti-rabbit IgG secondary antibody (A0208) was obtained from Beyotime Institute of Biotechnology (Haimen, China). SP Immunohistochemical kit (SP-9000) was a product of Beijing Zhongshan Golden Bridge Biotechnology Co., Ltd. (Beijing, China). Enhanced chemiluminescence (ECL) substrate kit was obtained from PerkinElmer, Inc. (Waltham, MA, USA). Cell Counting Kit-8 (CCK-8) was obtained from Beyotime Institute of Biotechnology. Triton ${ }^{\mathrm{TM}} \mathrm{X}-100$ was obtained from Sigma-Aldrich (St. Louis, MO, USA).

Experimental cells and design. Human A549 type II alveolar epithelial cell lines (purchased from the Cell Center of the Institute of Basic Medical Sciences, Peking Union Medical College (Beijing, China) were cultured in RPMI-1640 medium containing $10 \% \mathrm{FBS}$ in a $37^{\circ} \mathrm{C}$ and $5 \% \mathrm{CO}_{2}$ incubator. The cultured cells were divided into four groups: Control (untreated A549 cells); $\mathrm{SiO}_{2}$-stimulated $\left(50 \mathrm{mg} / \mathrm{ml} \mathrm{SiO}_{2}\right.$ composite suspension-treated A549 cells); AQP1 inhibitor [A549 cells were treated with $0.2 \mathrm{mmol} / \mathrm{l}$ mercury (II) chloride $\left(\mathrm{HgCl}_{2}\right)$ for 3 min and then $\mathrm{SiO}_{2}$-stimulated]; and AQP4 inhibitor [A549 cells were treated with $100 \mu \mathrm{mol} / 12$-(nicotinamide)-1,3,4thiadiazole (TGN-020) for $2 \mathrm{~h}$ and then $\mathrm{SiO}_{2}$-stimulated] (13).

Detection of $\mathrm{SiO}_{2}$ influence on the growth of $\mathrm{A} 549$ cells by CCK-8 assay. A549 cells were transferred into 96-well plates at 5,000 cells/well. Following acclimatization in $100 \mu \mathrm{l}$ RPMI-1640 containing $0.4 \%$ FBS for $24 \mathrm{~h}$, cells were stimulated with mixed suspensions of $\mathrm{SiO}_{2}$ particles for $24 \mathrm{~h}(10,25$, 50 or $100 \mathrm{mg} / \mathrm{ml}$ in RPMI-1640 containing 10\% FBS). Cell counting kit- 8 reaction solutions $(20 \mu \mathrm{l})$ were subsequently added to the wells (6 wells/group). Cell growth was measured by absorbance at $450 \mathrm{~nm}$ on a microplate reader $1 \mathrm{~h}$ later. The dose of $50 \mathrm{mg} / \mathrm{ml} \mathrm{SiO}_{2}$ was thus selected as the stimulus in subsequent experiments.

Reverse transcription (RT)-qPCR analysis. A549 cells were transferred to 6-well plates at 20,000 cells/well for $24 \mathrm{~h}$. Cells were treated as described in the previous section ( 3 wells/group). Total cellular RNA extraction was performed using TRIzol ${ }^{\circledR}$ reagent according to the manufacturer's instructions. RNA was reverse transcribed to complementary (c) DNA by incubation with reverse transcriptase at $42^{\circ} \mathrm{C}$ for $50 \mathrm{~min}$. qPCR analysis was performed in a Roter-Gene 3000 Sequence Detection System (Qiagen Pty Ltd., Melbourne, Australia) using SYBR Green PCR Master Mix. PCR amplification was performed on $0.5 \mu \mathrm{l}$ of cDNA using the following gene-specific primers: AQP1 forward, 5'-TGACCCGCTCGGACTTACT-3' and reverse, 3'-CTTCTGGACCCATGCTGTG-5'; AQP4 forward, 5'-CATCTCCCTTTGCTTTGGACTC-3' and reverse, 3'-CAG ATAGAGGATTCCTGCTCCAA- 5 '; and $\beta$-actin forward, 5'-CACCCCCACTGAAAAAGATGA-3' and reverse, 5'-CAT CTTCAAACCTCCATGACG-3'. The following conditions were used: A 1 min pre-denaturing step at $95^{\circ} \mathrm{C}$; and cycles of $15 \mathrm{sec}$ at $95^{\circ} \mathrm{C}$ and $20 \mathrm{sec}$ at $59^{\circ} \mathrm{C}$. A total of 40 cycles were performed to prevent saturation of the reaction. Melting curve analysis revealed a single sharp peak with the correct melting temperature. GAPDH was used as an internal control, and AQP1 and AQP4 mRNA expression was normalized against GAPDH expression. Relative quantification by the $2^{-\Delta \Delta \mathrm{Cq}}$ method was performed by comparing to control groups (18).

Western blotting. A549 cells were transferred to 6-well plates at 20,000 cells/well for $24 \mathrm{~h}$. Cells were treated as described in the previous section (3 wells/group). Proteins were extracted from cells using radioimmunoprecipitation assay buffer (catalog no. P0013; Beyotime Institute of Biotechnology, Haimen, China), and quantified by a bicinchoninic acid assay (catalog no. P0012; Beyotime Institute of Biotechnology). A total of $30 \mu \mathrm{g}$ extracted protein was loaded onto a $12 \%$ SDS-PAGE gel, subjected to electrophoresis at $120 \mathrm{~V}$ for $90 \mathrm{~min}$ and transferred to a nitrocellulose membrane (Whatman; GE Healthcare Life Sciences). Following blocking with 5\% skim milk in Tris-buffered saline with $0.1 \%$ Tween (TBST) at room temperature for $2 \mathrm{~h}$, the membranes were incubated with primary antibodies at $4^{\circ} \mathrm{C}$ overnight (anti-rat AQP1 and AQP4; 1:800). Membranes were washed in TBST three times, and incubated with the HRP-conjugated secondary antibody at room temperature for $2 \mathrm{~h}$ (anti-rat antibodies; 1:1,000). Protein bands were visualized using ECL. All western blotting densitometry data were normalized to $\beta$-actin using Image Lab software version 4.0 (Bio-Rad Laboratories, Inc., Hercules, CA, USA).

Immunocytochemical staining. A549 cells were cultured for $24 \mathrm{~h}$ in 24 -well plates at 5,000 cells/well; sterile coverslips were placed in each well in advance to allow cells to adhere during growth. The cells were fixed in $1 \%$ paraformaldehyde for $15 \mathrm{~min}$ and rinsed three times by phosphate-buffered saline, and incubated with $0.1 \%$ Triton X-100 in phosphate-buffered saline at room temperature for $5 \mathrm{~min}$. Normal goat serum blocking fluid (taken from the SP-9000 Immunohistochemical kit; Beijing Zhongshan Golden Bridge Biotechnology Co., Ltd.) was added for $15 \mathrm{~min}$, and cells were subsequently incubated with primary antibodies recognizing AQP1 and AQP4 (1:100) overnight, followed by the biotinylated secondary antibody and finally the S-A/HRP reagent taken from the SP-9000 Immunohistochemical kit; Beijing Zhongshan Golden Bridge Biotechnology Co., Ltd.) for 15 min. Immunoreactivity was visualized with DAB (Beijing Zhongshan Golden Bridge Biotechnology Co., Ltd.). Brown staining was considered to indicate a positive result. Staining was visualized using an optical microscope at magnification, x20 (Olympus Corporation, Tokyo, Japan). Cells that were stained a brown color were considered positive. Immunocytochemistry was quantified using Image-Pro Plus analysis software version 5.0 (Media 
Cybernetics, Inc., Rockville, MD, USA) to detect positive cells and automatically determine the optical density and percentage per field, which were used to calculate the expression levels of AQP1 and AQP4 protein in A549 cells. All sections were incubated under identical conditions with the same concentration of antibodies therefore the immunostaining was comparable among the various experimental groups.

Statistical analysis. All experiments were performed three times and all statistical analyses were performed using SPSS version 17.0 (SPSS Inc., Chicago, IL, USA). Statistical comparisons were performed using a Student's $t$-test for unpaired samples and a one-way analysis of variance for multiple comparisons. Post hoc comparisons were performed using the Least Significant Difference test when equal variances were assumed or with Dunnett's test when equal variances were not assumed. Data are expressed as the mean \pm standard error. $\mathrm{P}<0.05$ was considered to indicate a statistically significant difference.

\section{Results}

Influence of various concentrations of $\mathrm{SiO}_{2}$ on the growth of A549 cells. CCK-8 assay absorbance of A549 cells reduced following stimulation with various concentrations of $\mathrm{SiO}_{2}$, suggesting cell growth suppression (Fig. 1). The suppression was similar for $\mathrm{SiO}_{2}$ concentrations of 25 and $50 \mathrm{mg} / \mathrm{ml}$, at 78 and $76 \%$ of the control, respectively. Although $100 \mathrm{mg} / \mathrm{ml}$ $\mathrm{SiO}_{2}$ produced the greatest suppression of cell activity, it led to increased cell death and influenced the detection of mRNA and protein of AQP1 and AQP4. Therefore $50 \mathrm{mg} / 1$ was selected as the stimulus concentration for the subsequent experiments.

The expression levels of $A Q P 1$ and AQP4 $m R N A$ in A549 cells exposed to $\mathrm{SiO}_{2}$. Following $\mathrm{SiO}_{2}$ stimulation, the AQP1 mRNA expression levels increased rapidly compared with the control group ( 0.5 and $1 \mathrm{~h}$, both $\mathrm{P}<0.001$ vs. control group), and peaked at $2 \mathrm{~h}\left(\mathrm{P}<0.001\right.$ vs. control group) post $\mathrm{SiO}_{2}$ treatment (Fig. 2). From $2 \mathrm{~h}$ onwards there was a gradual decrease, and this difference ( 2 vs. 4 and 8 h) was statistically significant (both $\mathrm{P}<0.001$ ). Following exposure to $\mathrm{SiO}_{2}$ for $8 \mathrm{~h}$, the mRNA expression levels of AQP1 returned to those of the control group. Pretreatment of cells with AQP1 inhibitor prior to stimulation with $\mathrm{SiO}_{2}$ for $2 \mathrm{~h}$ resulted in significantly decreased AQP1 mRNA expression levels compared with the $\mathrm{SiO}_{2}$-stimulated group at $2 \mathrm{~h}(\mathrm{P}<0.001)$. The AQP4 mRNA expression levels in A549 cells followed a similar pattern (0.5, 1 and $2 \mathrm{~h}, \mathrm{P}<0.001$ vs. control group; 1 vs. $2 \mathrm{~h} \mathrm{P}=0.023 ; 1$ vs. 4 h, $\mathrm{P}<0.001 ; 1$ vs. 8 h, $\mathrm{P}<0.001$; Fig. 2).

Western blot analysis of $A Q P 1$ and AQP4 protein expression levels in $\mathrm{A} 549$ cells exposed to $\mathrm{SiO}_{2}$. Western blotting (Fig. 3) revealed that $\mathrm{SiO}_{2}$ treatment led to an increase in the expression levels of AQP1 protein in A549 cells. The increase was observed at $3 \mathrm{~h}$ of stimulation and peaked at $6 \mathrm{~h}$. Protein expression levels declined from $12 \mathrm{~h}$; however, at $24 \mathrm{~h}$ they remained greater than in the control group $(\mathrm{P}=0.021)$. Following pretreatment with inhibitor, AQP1 protein expression levels were increased compared with those of the control group $(\mathrm{P}<0.001)$; however, they were reduced compared with

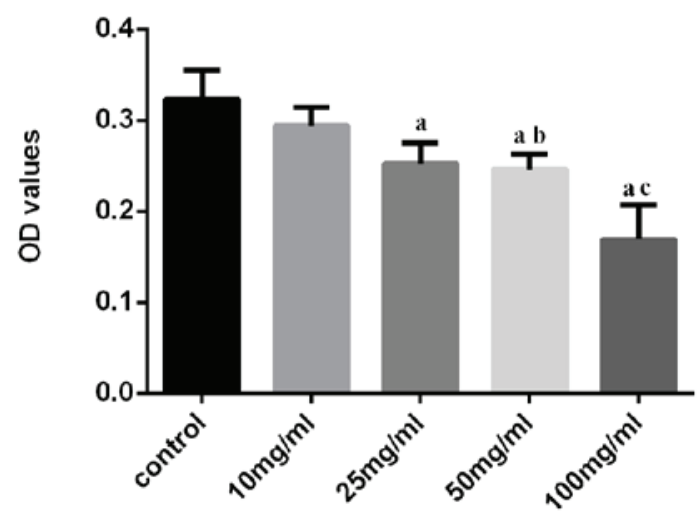

Figure 1. Selection of $\mathrm{SiO}_{2}$ concentration for stimulation of A549 cells investigated by CCK- 8 assay. A549 cells were stimulated with mixed suspensions of $\mathrm{SiO}_{2}$ particles $(10,25,50$ and $100 \mathrm{mg} / \mathrm{ml})$. CCK-8 assay absorbance for A549 cells was reduced following $\mathrm{SiO}_{2}$ stimulation, suggesting that cell growth was suppressed, and the suppression rate for the cells following treatment with 25 and $50 \mathrm{mg} / \mathrm{ml} \mathrm{SiO}_{2}$ was similar at 78 and $76 \%$, respectively. Therefore, $50 \mathrm{mg} / \mathrm{ml} \mathrm{SiO}$, was selected as the stimulus concentration for subsequent experiments. OD, optical density; CCK-8, cell counting Kit-8. ${ }^{\mathrm{a}} \mathrm{P}<0.01$ vs. control; ${ }^{\mathrm{b}} \mathrm{P}<0.05$ vs. $10 \mathrm{mg} / \mathrm{ml}$; and ${ }^{\mathrm{c}} \mathrm{P}<0.01$ vs. $50 \mathrm{mg} / \mathrm{ml}$.

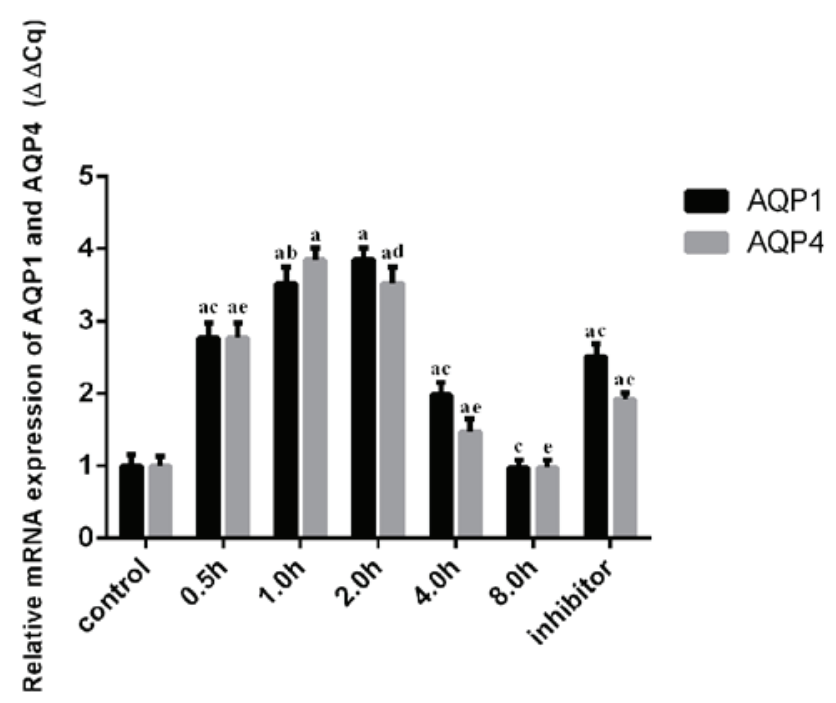

Figure 2. Expression levels of AQP1 and AQP4 mRNA in A549 cells exposed to $\mathrm{SiO}_{2}$. AQP1 mRNA expression levels in $\mathrm{SiO}_{2}$-stimulated groups increased rapidly and peaked at $2 \mathrm{~h}$ following $\mathrm{SiO}_{2}$ treatment, then gradually decreased. By $8 \mathrm{~h}$, the mRNA expression level of AQP1 had returned to that of the control group. AQP1 inhibitor, used at $0 \mathrm{~h}$ and detected at $2 \mathrm{~h}$, decreased the mRNA expression levels of AQP1. The AQP4 mRNA expression levels in A549 cells followed a similar pattern; however, the peak was observed at $1 \mathrm{~h}$. ${ }^{\mathrm{a}} \mathrm{P}<0.01$ vs. control; ${ }^{b} \mathrm{P}<0.05$ and ${ }^{\mathrm{C}} \mathrm{P}<0.01$ vs. $2 \mathrm{~h}$ $\mathrm{SiO}_{2}$ stimulation; and ${ }^{\mathrm{d}} \mathrm{P}<0.05$ and ${ }^{\mathrm{e}} \mathrm{P}<0.01$ vs. $1 \mathrm{~h} \mathrm{SiO}_{2}$ stimulation. AQP, aquaporin; $\mathrm{SiO}_{2}$, silicon dioxide.

the $\mathrm{SiO}_{2}$-stimulated group at $6 \mathrm{~h}(\mathrm{P}<0.001)$. AQP4 protein expression levels were increased in the $\mathrm{SiO}_{2}$-stimulated groups compared with the control group ( $3 \mathrm{~h}, \mathrm{P}=0.001)$, and peaked at $6 \mathrm{~h}(\mathrm{P}<0.001)$. Following pretreatment with inhibitor, AQP4 protein expression levels remained increased compared with those of the control group $(\mathrm{P}=0.014)$; however, they were reduced compared with the $\mathrm{SiO}_{2}$-stimulated group at $6 \mathrm{~h}$ $(\mathrm{P}<0.001)$. 


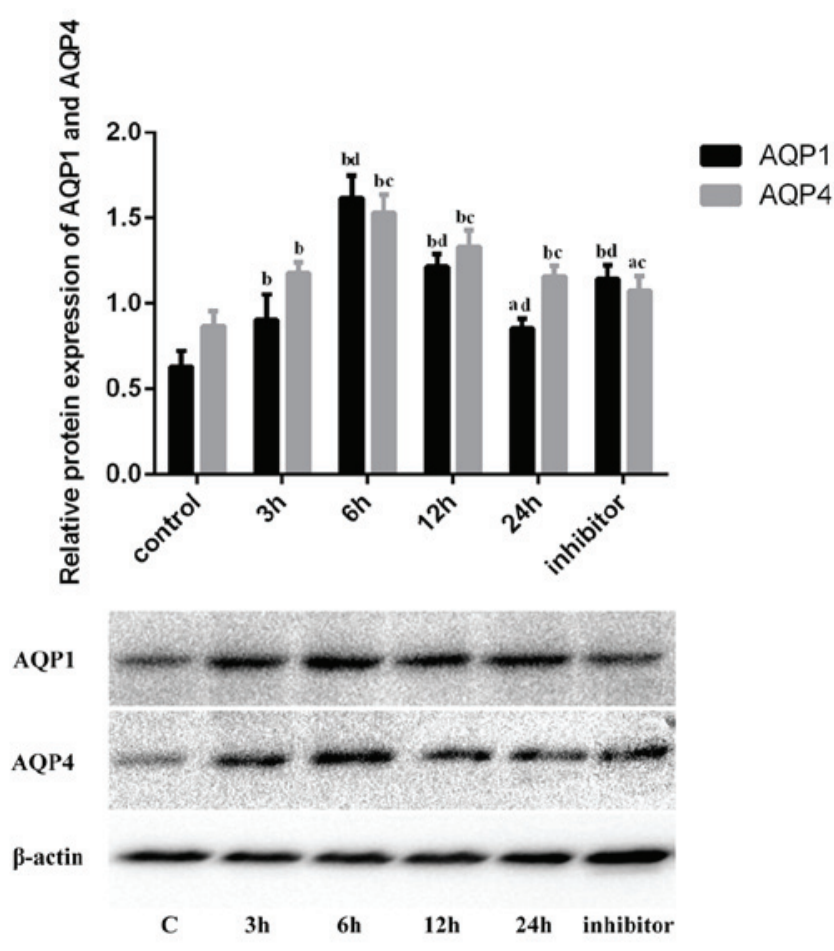

Figure 3. Expression levels of AQP1 and AQP4 protein in A549 cells exposed to $\mathrm{SiO}_{2}$. Western blotting revealed that $\mathrm{SiO}_{2}$ treatment increased protein expression levels of AQP1 and AQP4 in A549 cells. This increase was observed following $3 \mathrm{~h}$ of stimulation and peaked at $6 \mathrm{~h}$, declining from $12 \mathrm{~h}$. Following pretreatment with inhibitors (used at $0 \mathrm{~h}$ and detected at $6 \mathrm{~h}$ ), AQP1 and AQP4 protein expression levels were increased compared with the control group; however, they were reduced compared with the $\mathrm{SiO}_{2}$-stimulated group at $6 \mathrm{~h} .{ }^{\mathrm{a}} \mathrm{P}<0.05$ and ${ }^{\mathrm{b}} \mathrm{P}<0.01$ vs. control; and ${ }^{\mathrm{c}} \mathrm{P}<0.05$ and ${ }^{\mathrm{d}} \mathrm{P}<0.01$ vs. $6 \mathrm{~h} \mathrm{SiO}_{2}$ stimulation. $\mathrm{AQP}$, aquaporin; $\mathrm{C}$, control.

Immunocytochemistry staining evaluation. AQP1 and AQP4 immunocytochemistry staining products appeared brown (Fig. 4) and were expressed in the cytoplasm and nucleus. The immunocytochemistry quantitative analysis revealed that $\mathrm{AQP1}$ protein expression levels were increased compared with untreated cells at $3(\mathrm{P}=0.004), 6(\mathrm{P}<0.001)$ and $12 \mathrm{~h}(\mathrm{P}<0.001)$ following $\mathrm{SiO}_{2}$ exposure and gradually declined from $6 \mathrm{~h}$ until similar to control levels at $24 \mathrm{~h}(\mathrm{P}=0.153)$. Following pretreatment with inhibitor, AQP1 expression levels decreased $29 \%$ compared with the $\mathrm{SiO}_{2}$-stimulated group at $6 \mathrm{~h}(\mathrm{P}<0.001)$. The AQP4 protein expression levels in A549 cells followed a similar pattern (Fig. 4).

\section{Discussion}

The water balance of the body is important for the maintenance of health. The AQP family is crucial in this balance and is closely associated with the development of various diseases. Therefore, AQPs have attracted attention as targets for the treatment of numerous diseases (19). To date, $13 \mathrm{AQP}$ isoforms (AQP0-AQP12) have been identified in mammals and are expressed in diverse tissues (20-22), and $6 \mathrm{AQPs}(\mathrm{AQP} 1, \mathrm{AQP} 3, \mathrm{AQP} 4, \mathrm{AQP} 5, \mathrm{AQP} 8$ and AQP9) are expressed in the lung and airways $(23,24)$. AQP1 is expressed in the microvascular endothelia, AQP3 and AQP4 in the airway epithelia and AQP5 in type I alveolar epithelial cells, submucosal gland acini and a subset of airway

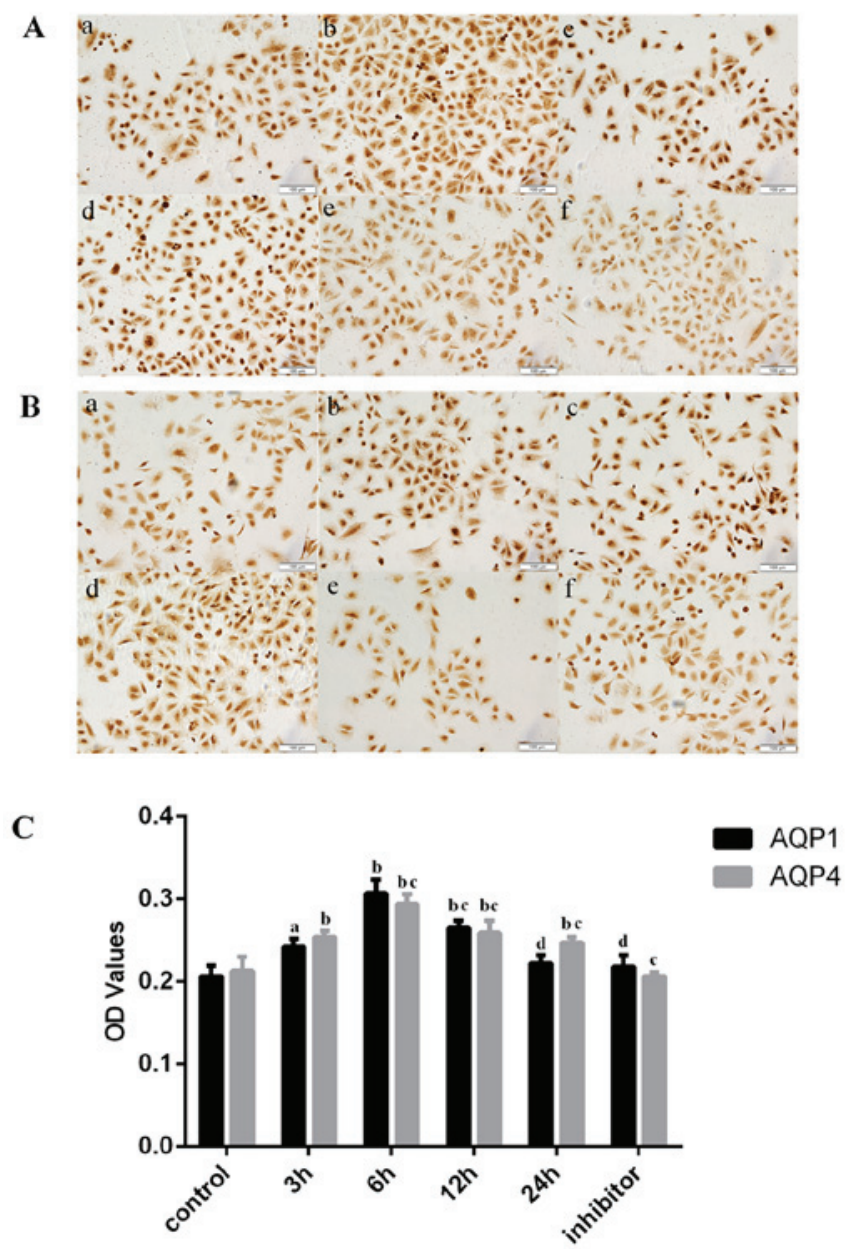

Figure 4. Immunocytochemistry staining and evaluation (A) AQP1 and (B) AQP4 immunocytochemistry staining products were brown and expressed in the cytoplasm and nucleus of: A, control cells; b, cells stimulated by $\mathrm{SiO}_{2}$ for $3 \mathrm{~h}$; c, cells stimulated by $\mathrm{SiO}_{2}$ for $6 \mathrm{~h}$; d, cells stimulated by $\mathrm{SiO}_{2}$ for $12 \mathrm{~h}$; e, cells stimulated by $\mathrm{SiO}_{2}$ for $24 \mathrm{~h}$; and f, cells pretreated with inhibitor. (C) AQP1 and AQP4 expression levels in A549 cells followed similar patterns, increasing at 3,6 and $12 \mathrm{~h}$ following $\mathrm{SiO}_{2}$ exposure compared with the control and gradually declining from $6 \mathrm{~h}$ until similar to control levels at $24 \mathrm{~h}$. Following pretreatment with inhibitor (at $0 \mathrm{~h}$ and detected at $6 \mathrm{~h}$ ), expression levels declined $29 \%$ compared with the $\mathrm{SiO}_{2}$-stimulated group at 6 h. ${ }^{\text {a }} \mathrm{P}<0.05$ and ${ }^{b} \mathrm{P}<0.01$ vs. control; and ${ }^{\mathrm{c}} \mathrm{P}<0.05$ and ${ }^{\mathrm{d}} \mathrm{P}<0.01$ vs. $6 \mathrm{~h} \mathrm{SiO}_{2}$ stimulation. AQP, aquaporin; OD, optical density.

epithelial cells (10). Although AQP8 and AQP9 protein expression has been observed in the lung, immunolocalization of these proteins has not yet been demonstrated $(25,26)$. AQP1 is the primary water channel responsible for water transport through numerous epithelia and endothelia (10). In addition, a previous study suggested important roles for this protein in gas permeation, angiogenesis, cell proliferation and migration (27). The expression of AQP1 protein may be mechanistically involved in the airway inflammation and pathogenesis of chronic obstructive pulmonary disease (COPD) (28), and expression of AQP1 increased markedly in pulmonary fibrosis, suggesting that AQP1 may be important in the progression of this disease (12). However, in our previous study it was demonstrated that the expression of AQP1 increased first and then declined in the lung tissue of silicosis rats, suggesting that AQP1 may potentially be involved in the pathogenesis of silicosis (17). 
This phenomenon also existed in rat lung infection and endotoxin-induced lung injury, and a study observed mouse lung AQP-1 and AQP-5 were downregulated (29). This may be due to the disorder of water balance caused by silica dust. AQP4 is primarily distributed in the airway epithelium, alveolar endothelial and epithelial cells (29). A previous study revealed that AQP4 expression was significantly increased in cells from patients with asthma (30). However, in other respiratory diseases, including COPD, patients also demonstrated decline of AQP4 mRNA expression (31). This varying expression of AQP4 may be due to the nature and different stages of these diseases. In addition, AQP4 has been associated with the tumorigenesis and migration of lung adenocarcinoma, potentially promoting lung adenocarcinoma cancer cell migration via adjustment of E-cadherin protein expression levels (32).

In pulmonary diseases, lung epithelial cells are highly susceptible to become targets for damage (33). In the development of silicosis, $\mathrm{SiO}_{2}$ is the initiating factor, and upon entering the body it affects alveolar epithelial cells, particularly in the acute phase of lung injury. Notably, at this stage the inflammatory response is pronounced and increased vascular permeability and pulmonary edema follow (29). The pathway for the transport of water across the endothelial and epithelial lung barrier remains to be fully elucidated; however, AQPs have been described as critical in water removal from the lung extracellular space (30). The present study was designed to observe the alteration of AQP1 and AQP4 expression levels in A549 cells exposed to $\mathrm{SiO}_{2}$, to indicate whether a water imbalance within lung epithelial cells exists in acute lung injury resulting from $\mathrm{SiO}_{2}$ stimulation.

The results of the present study demonstrated that the expression levels of AQP1 and AQP4 mRNA increased in A549 cells following exposure to $\mathrm{SiO}_{2}$, and that this increased expression was inhibited by pretreatment with specific inhibitors of AQP1 and AQP4, $\mathrm{HgCl}_{2}$ and TGN-020, respectively. Notably, by immunocytochemistry, inhibitor reduced AQP protein expression to control levels, whereas by western blot analysis, it did not. This may be due to differential sensitivity of various methods and measurement software. The alterations in AQP1 and AQP4 expression levels may therefore be associated with $\mathrm{SiO}_{2}$ stimulation and these proteins may contribute to A549 cell damage. Alterations in AQP1 and AQP4 expression levels may induce the imbalance of lung epithelial water transportation. This may exacerbate acute inflammatory damage of lung tissue, which may then gradually develop into chronic hyperplastic lesions, ultimately resulting in silicosis fibrosis. However, the specific underlying mechanism remains to be elucidated.

The acute inflammatory damage stage induced by $\mathrm{SiO}_{2}$ may be crucial for the early occurrence and development of silicosis (1). Early application of specific inhibitors of water channel proteins may thus reverse the imbalance of lung epithelial water transportation, and decrease or even prevent the inflammatory reaction caused by $\mathrm{SiO}_{2}$ stimulation and so reduce the degree of silicosis fibrosis (34). Therefore, AQP1 and AQP4 may become novel targets for silicosis prevention and early treatment (35-37).

Although $\mathrm{HgCl}_{2}$ and TGN-020 act as specific inhibitors for AQP1 and AQP4 and effectively inhibit their expression $(35,38)$, the results of the present study suggest that they have specific cell toxicity. The identification and development of novel water channel protein inhibitors is therefore required for use in the prevention and treatment of silicosis.

There are numerous AQPs in lung tissue, and in the present study only the expression of AQP1 and AQP4 was investigated; therefore, the expression of other AQPs and their roles in silicosis requires additional investigation. Research into the role of AQPs in the pathogenesis of silicosis is at an early stage; however, novel therapeutic agents targeting AQP have been identified (39-41). Additional studies are necessary to clarify the causal association between AQP1 and AQP4 upregulation and the development of silicosis, and to determine whether AQP1 and AQP4 are suitable targets for silicosis treatment or prevention.

In conclusion, the results of the present study demonstrated that the expression of AQP1 and AQP4 increased when exposed to $\mathrm{SiO}_{2}$, and that the specific inhibitors $\mathrm{HgCl}_{2}$ and TGN-020 inhibited this $\mathrm{SiO}_{2}$-stimulated increase. This suggests that AQP1 and AQP4 may contribute to A549 cell damage induced by $\mathrm{SiO}_{2}$. AQP1 and AQP4 may thus be involved in the initiation and development of silicosis.

\section{References}

1. Leung CC, Yu IT and Chen W: Silicosis. Lancet 379: 2008-2018, 2012.

2. Guha N, Straif K and Benbrahim-Tallaa L: The IARC monographs on the carcinogenicity of crystalline silica. Med Lav 102: 310-320, 2011.

3. Zhang $\mathrm{H}$, Yin G, Jiang $\mathrm{H}$ and Zhang C: High-dose N-acetylcysteine decreases silica-induced lung fibrosis in the rat. J Int Med Res 41: 1179-1186, 2013.

4. Steenland K and Ward E: Silica: A lung carcinogen. CA Cancer J Clin 64: 63-69, 2014.

5. Chu L, Wang T, Hu Y, Gu Y, Su Z and Jiang H: Activation of Egr-1 in human lung epithelial cells exposed to silica through MAPKs signaling pathways. Plus One 8: e68943, 2013.

6. Ishibashi K, Kondo S, Hara S and Morishita Y: The evolutionary aspects of aquaporin family. Am J Physiol Regul Integr Comp Physiol 300: R566-R576, 2011.

7. Li G, Santoni V and Maurel C: Plant aquaporins: Roles in plant physiology. Biochim Biophys Acta 1840: 1574-1582, 2014.

8. Sahdeva R and Singh B: Insights into structural mechanisms of gating induced regulation of aquaporins. Prog Biophys Mol Biol 114: 69-79, 2014.

9. Preston GM and Agre P: Isolation of the cDNA for erythrocyte integral membrane of 28 kilodaltons: Member of an ancient channel family. Proe Natl Acad Sci USA 88: 11110-11114, 1991.

10. Verkman AS: Role of aquaporins in lung liquid physiology. Respir Physiol Neurobiol 159: 324-330, 2007.

11. Benga G: The first discovered water channel protein, later called aquaporin 1: Molecular characteristics, functions and medical implications. Mol Aspects Med 33: 518-534, 2012.

12. Gao X, Wang G, Zhang W, Peng Q, Xue M and Jinhong H: Expression of pulmonary aquaporin 1 is dramatically upregulated in mice with pulmonary fibrosis induced by bleomycin. Arch Med Sci 9: 916-921, 2013.

13. Zhang QY, Fu JH and Xue XD: Expression and function of aquaporin-1 in hyperoxia-exposed alveolar epithelial type II cells. Exp Ther Med 8: 493-498, 2014.

14. Ebeling G, Bläsche R, Hofmann F, Augstein A, Kasper M and Barth K: Effect of P2X7 receptor knockout on AQP-5 expression of type I alveolar epithelial cells. PLoS One 9: e100282, 2014

15. Warth A, Muley T, Meister M, Herpel E, Pathil A, Hoffmann H, Schnabel PA, Bender C, Buness A, Schirmacher P and Kuner R: Loss of aquaporin-4 expression and putative function in non-small cell lung cancer. BMC Cancer 11: 161, 2011.

16. Hao XH, Wang HL, Liu HL, Zhang L and Li YH: Effect of curcumin on expression of aquaporin-1 in lung tissue of silicotic rats. Zhongguo Zhi Ye Yi Xue 39: 471-474, 2012 (In Chinese). 
17. Zhang L, Hao XH, Wang HL, Zhao JY and Liu HL: Expression and significance of aquaporin 1 in lung tissue of silicotic rats. Zhongguo Gongye Yixue Zazhi 25: 91-93 and 161, 2012 (In Chinese).

18. Livak KJ and Schmittgen TD: Analysis of relative gene expression data using real-time quantitative PCR and the 2(-Delta Delta C(T)) method. Methods 25: 402-408, 2001.

19. Day RE, Kitchen P, Owen DS, Bland C, Marshall L, Conner AC, Bill RM and Conner MT: Human aquaporins: Regulators of transcellular water flow. Biochim Biophys Acta 1840: 1492-1506, 2014.

20. Matsuzaki T, Tajika Y, Tserentsoodol N, Suzuki T, Aoki T, Hagiwara $\mathrm{H}$ and Takata $\mathrm{K}$ : Aquaporins: A water channel family. Anat Sci Int 77: 85-93, 2002.

21. Ishibashi K: Aquaporin subfamily with unusual NPA boxes Biochim Biophys Acta 1758: 989-993, 2006.

22. Takata K, Matsuzaki T and Tajika Y: Aquaporins: Water channel proteins of the cell membrane. Prog Histochem Cytochem 39: $1-83,2004$

23. Singha O, Kengkoom K, Chaimongkolnukul K, Cherdyu S, Pongponratn E, Ketjareon T, Panavechkijkul Y and Ampawong S: Pulmonary edema due to oral gavage in a toxicological study related to aquaporin-1, -4 and -5 expression. J Toxicol Pathol 26 : 283-291, 2013

24. Alimit A, Hasan B, Lu W, Qin W, Wushouer Q, Zhong N and Upur $\mathrm{H}$ : Changes in water channel aquaporin 1 and aquaporin 5 in the small airways and the alveoli in a rat asthma model. Micron 45: 68-73, 2013.

25. Elkjaer ML, Nejsum LN, Gresz V, Kwon TH, Jensen UB, Frøkiaer J and Nielsen S: Immunolocalization of aquaporin-8 in rat kidney, gastrointestinal tract, testis, and airways. Am J Physiol Renal Physiol 281: F1047-F1057, 2001.

26. Tsukaguchi H, Weremowicz S, Morton CC and Hediger MA Functional and molecular characterization of the human neutra solute channel aquaporin-9. Am J Physiol 277: F685-F696. 1999

27. La Porta C: AQP1 is not only a water channel: It contributes to cell migration through Lin7/beta-catenin. Cell Adh Migr 4: 204-206, 2010

28. Calero C, López-campos JL, Izouierdo LG, Sánchez-Silva R, López-Villalobos JL, Sáenz-Coronilla FJ, Arellano-Orden E, Montes-Worboys A and Echevarría M: Expression of aquaporins in bronchial tissue and lung parenchyma of patients with chronic obstructive pulmonary disease. Multidiscip Respir Med 9: 29, 2014.
29. Shen Y, Wang X, Wang Y, Wang X, Chen Z, Jin M and Bai C: Lipopolysaccharide decreases aquaporin 5, but not aquaporin 3 or aquaporin 4 , expression in human primary bronchial epithelial cells. Respirology 17: 1144-1149, 2012.

30. Jardim MJ, Dailey L, Silbajoris R and Diaz-Sanchez D: Distinct microRNA expression in human airway cells of asthmatic donors identifies a novel asthma-associated gene. Am J Respir Cell Mol Biol 47: 536-542, 2012.

31. Zhu B, Yang L and Chen T: Relationship between AQP4 mRNA expression in bronchial epithelium of patients with COPD and the airway inflammation. Xi'an Jiaotong Daxue Xuebao (Yexueban) 29: 656-658 and 678, 2008 (In Chinese).

32. McCoy E and Sontheimer H: Expression and function of water channels (aquaporins) in migrating malignant astrocytes. Glia 55: 1034-1043, 2007.

33. Grainge CL and Davies DE: Epithelial injury and repair in airways diseases. Chest 144: 1906-1912, 2013.

34. Xie Y, Wen X, Jiang Z, Fu H, Dai L and Han H: Correlation between exression of aquaporin 4 and migration ability and growth of lung adenocarcinoma cells. Huazhong Keji Daxue Xuebao (Yixueban) 40: 682-685, 2011 (In Chinese).

35. Mola MG, Nicchia GP, Svelto M, Spray DC and Frigeri A: Automated cell-based assay for screening of aquaporin inhibitors. Anal Chem 81: 8219-8229, 2009.

36. Verkman AS, Anderson MO and Papadopoulos MC: Aquaporins: Important but elusive drug targets. Nat Rev Drug Discov 13: 259-277, 2014.

37. Jullienne A and Badaut J: Molecular contributions to neurovascular unit dysfunctions after brain injuries: Lessons for target-specific drug development. Future Neurol 8: 677-689, 2013.

38. Moon HG, Zheng Y, An CH, Kim YK and Jin Y: CCN1 secretion induced by cigarette smoking extracts augments IL-8 release from bronchial epithelial cells. Plos One 8: e68199, 2013.

39. von Bülow J: Aquaporins-water channels in the cell membrane and therapeutic targets. Med Monatsschr Pharm 36: 86-94; quiz 95-96, 2013 (In German).

40. Xie Y, Wen X, Jiang Z, Fu HQ, Han H and Dai L: Aquaporin 1 and aquaporin 4 are involved in invasion of lung cancer cells. Clin Lab 58: 75-80, 2012.

41. Frede J, Fraser SP, Oskay-Özcelik G, Hong Y, Ioana Braicu E, Sehouli J, Gabra H and Djamgoz MB: Ovarian cancer: Ion channel and aquaporin expression as novel targets of clinical potential. Eur J Cancer 49: 2331-2344, 2013. 